\title{
A Délvidék elszakítása: Újvidék 1918. november 25.
}

\author{
Gulyás László*
}

\begin{abstract}
Territorial division of Délvidék: Újvidék, November 25, 1918. Before 1918, Délvidék was a multi-ethnic region where Hungarians, Serbs, Romans and Germans, along with half a dozen additional nations/ethnicities, maintained one of the economically most developed region of the dualist state. Tensions among these nations escalated during the autumn of 1918. The Serbian populace of the region attempted to have Délvidék annexed to the Kingdom of Serbia. To this end, the Serbs held a Great Assembly on November 25, 1918 in Újvidék, where the region joining the Serbian kingdom was declared. Our paper presents the background and the course of this assembly.
\end{abstract}

Keywords Great War (1914-1918), history of Central-Europe, history of Kingdom of Serbia, birth of the first Yugoslav state, Újvidék

\section{Bevezetés}

Az első világháború kitörésekor még nem létezett jugoszláv állam. Bár többféle elképzelés létezett egy olyan délszláv állam felállítására, amely valamennyi horvátot, szerbet, szlovént a keretei közé zár. A Szerb-Horvát-Szlovén Királyság megszületése 1918. december 1-jén több szimbolikus eseményhez, és ezek több egymástól igen távollévő helyszínhez köthetők. Ilyen helyszínek voltak Korfu, Zágráb, Genf, Újvidék és Belgrád. Jelen tanulmányban az Újvidéken történteket mutatjuk be.

\section{A Délvidéki szerbek szervezkedése}

A Délvidéken a dualista magyar állam keretei között élő délszlávok politikai szervezkedése már 1918 októberében megkezdődött. A szabadkai szerb értelmiségiek egy csoportja Tihomir Ostojić vezetésével 1918. október 2-án titkos tanácskozást tartott, ahol arra az álláspontra jutottak, arra kell törekedniük, hogy a Bácska, a Bánát és Baranya a jugoszláv állam részévé váljon és ezt a békekonferencia szentesítse. ${ }^{1}$ A következő hetekben számos kisebb-nagyobb titkos találkozóra került sor, ahol a szerb politikusok világosan kimondták, hogy meg kell szakítani minden államjogi kapcsolatot Magyarországgal.

\footnotetext{
*Intézmény: Szegedi Tudományegyetem Juhász Gyula Pedagógusképző Kar Email: laszlo.gulyas65@gmail.com

${ }^{1}$ Končar, Ranko 2008,18-27.
} 
Miután október 29-én Zágrábban kikiáltották a Szlovén-Horvát-Szerb Államot ${ }^{2}$ a délvidéki szerb politikusok között vita bontakozott arról, hogy a Délvidék ehhez a Zágráb központú államhoz, vagy inkább a Szerb Királysághoz csatlakozzék-e. ${ }^{3}$

Ez a kérdés azért merült fel, mert mind a Szlovén-Horvát-Szerb Állam, mind a Szerb Királyság bejelentette igényét Bánát, Bácska és Baranya területére. A SzlovénHorvát-Szerb Állam katonai erő hiányában nem tudta kiterjeszteni uralmát ezekre a területekre, ezzel szemben a Szerb Királyság hadserege Belgrádból kiindulva már 1918. november 10-én elfoglalta Zimonyt és Pancsovát - ezek a települések a történelmi magyar határon belül feküdtek -, illetve bevonult a szintén történelmi Magyarország keretein belül elhelyezkedő Fehértemplomba. A szerb előrenyomulás ezután Bácskában és Baranyában az alábbi módon folytatódott:

- Zimonyról kiindulva megtörtént Újvidék (november 12.), majd Óbecse (november 13.) megszállása. Az elfoglalt Újvidékről kiindulva egy másik szerb alakulat Szabadkát (november 13) foglalta el.

- Az elfoglalt Újvidékről kiindulva egy harmadik szerb csapat Zombort (november 13.), majd Baját foglalta el (szintén november 13-a).

- A horvát terülten fekvő Eszék megszállására után (november 13.) a szerb hadsereg Pécset foglalta el (november 15), illetve sor került Szigetvár és Barcs megszállására is.

Míg a Bánságban az alábbi módon zajlott a megszállás:

- Pancsováról kiindulva megtörtént Nagybecskerek (november 13.), majd Nagykikinda elfoglalása (november 19). November végén a szerb hadsereg már a Maros folyó vonalánál állt.

- Fehértemplomról kiindulva történt meg Versec (november 15), elfoglalása, majd onnan tovább haladva Resicabányát (november 20) is megszállták.

- Szintén Versecböl kiindulva került sor Temesvár megszállására (november 20.). Innen kiindulva északi iránya Nagyszentmiklóst (november 20), míg keleti irányban Lugost (november 21) foglalták el.

Miközben november hónap folyamán a szerb hadsereg jelentős területeket foglalt el a Délvidékből, a régió kisebb-nagyobb városaiban különböző elnevezéssel szerb és bunyevác nemzeti tanácsok alakultak.

Ezek tevékenységének ellensúlyozására német és magyar nemzeti tanácsok is felálltak. November első két napján az alábbi településeken jöttek létre Magyar Nemzeti Tanácsok:

- november 1.: Pancsova, Versec, Újvidék, Zombor;

- november 2.: Feketics, Kishegyes, Martonos, Óbecse;

- november 5.: Sajkásszentiván.

A magyar nemzeti tanácsok mind kinyilvánították hűségüket a budapesti Nemzeti Tanácsnak. A kibontakozó nemzeti ellentéteket jól mutatja, hogy amikor Sajkásszentivánon a magyar megalakították a saját nemzeti tanácsukat, azt a szerb lakosság erőszakkal feloszlatta.

\footnotetext{
${ }^{2}$ A részleteket lásd Sokcsevits Dénes 2011, 476-477.

${ }^{3}$ Končar, Ranko 2008, uo.
} 
A három legfontosabb délszláv nemzeti tanács az alábbi volt:

- az Újvidéken 1918. november 3-án megalakult Szerb Nemzeti Tanács

- a Zomborban 1918. november 4-én megalakult Bunyevác-Szerb Nemzeti Tanács,

- a Szabadkán 1918. november 10-én megalakult Szerb Nemzeti Tanács.

Az újvidéki Szerb Nemzeti Tanács megalakulása utáni első ténykedése az volt, hogy kiáltványt intézett a délvidéki szerbekhez. Ebben a könyörtelen és példátlan magyar elnyomó politika ecsetelése után kijelentették, hogy kötelezettséget vállalnak arra, hogy a magyarországi szerbek és más délszlávok segítségére lesznek abban, hogy gyakorolhassák nemzeti önrendelkezési jogukat. Ennek érdekében a közeli jövőben egy szerb népgyülést fognak összehívni, mely ,határozhat majd a szerb nép igazi akaratáról." "4

A következő hetekben az Újvidéki Szerb Nemzeti Tanács egyre nagyobb súlyra tett szert a délszlávok megszervezése terén. Jól mutatja ezt, hogy levélben utasította a kisebb települések délszláv nemzeti tanácsait, hogy ne engedelmeskedjenek a Károlyi-kormány utasításainak, és kizárólag az Újvidéki Nemzeti Tanács utasításait fogadják el. ${ }^{5}$ A helyi szerb nemzeti tanácsok elfogadták ezt az irányvonalat. Nézzünk egy példát: amikor Balogh Ernő - Bács-Bodrog vármegye főispánja - azt javasolta a zombori szerb politikusoknak, hogy a zombori Bunyevác-Szerb Nemzeti hogy müködjenek együtt a budapesti Magyar Nemzeti Tanáccsal, azok ezt elutasították. ${ }^{6}$

A következő lépésben az Újvidéki Szerb Nemzeti Tanács 1918. november 17-én körlevelet küldött szét a Bácska, a Bánát és Baranya helységeibe, amelyben felszólította a szerbeket, a bunyevácokat és a „többi szlávokat”, hogy 1918. november 25 -én küldjék el delegátusaikat Újvidékre. A körlevél úgy fogalmazott, hogy ennek a népgyülésnek kell eldöntenie, hogy melyik államhoz akarnak tartozni. ${ }^{7}$

Az, hogy milyen döntés várható ezen az ülésen, már jól mutatta, hogy az egyik szemtanú szerint, amikor a bánsági szerbek küldöttei keresztül utaztak Szabadkán valamennyiük a karján széles szerb trikolort viselt, rajta „, Éljen Nagy-Szerbia!’ felirattal.

\section{A Nagy Nemzetgyülés}

Ilyen elözmények után ült össze 1918. november 25-én Újvidéken a Nagy Nemzetgyülés. A délvidéki szerbek egyik vezető politikusa, a Zágrábban tartózkodó Vasa Stajič, november 25-én táviratot küldött az összeülö népgyülés elnökségi tagjának, Ignat Pavlasnak. Ebben azt javasolta, hogy a nemzetgyülés ne mondja ki a Vajdaságnak a Szerb Királysághoz történő csatlakozást. Ehelyett azt tanácsolta, hogy a vajdaságiak alakítsanak önálló tartományi kormányt. Valószínüsíthetjük, hogy Stajič úgy gondolta, hogy ennek a tartományi kormánynak kell majd tárgyalnia a belgrádi kormánnyal az egyesülés módjáról. Gyakorlatilag nem egy közfelkiáltásos, hanem egy tárgyalásos egyesülést akart.

Csakhogy november 25-re a délvidéki szerbek másik vezető politikusa, Jaša Tomič aki a szerb államhoz történő azonnali csatlakozás álláspontja mellett kötelezte el magát - hívei döntő túlsúlyba kerültek a küldöttek között. amely az alábbi határozatott hozta:

\footnotetext{
${ }^{4}$ Közli Sloboda (a Magyarországi Szociáldemokrata Párt Szerb-Bunyevác Agitációs Bizottságának lapja, Újvidék) 1918. november 6.

${ }^{5}$ Mészáros Sándor 1998, 260-265.

${ }^{6}$ Kővágó László 1964, 89.

${ }^{7}$ Fogarassy László 1986, 540.
} 
„1. Felkérjük a testvéri Szerbia kormányát, hogy a békekongresszuson képviselje érdekeinket.

2. Csatlakozunk a Szerb Királysághoz, amely eddigi tevékenységével és fejlödésével nem csak számunkra, de valamennyi szláv és velünk élö nem szláv nép számára is garantálja a szabadaságot, az egyenlöséget és a minden irányú haladást.

3. Ez a követelés egyúttal támogatni kívánja a délszlávok törekvését, ... hogy Péter király és uralkodó háza vezetésével létrejöhessen a szerbek, horvátok és szlovének egységes állama." 8

Mint látható a Nagy Nemzetgyülés kimondta a Bánát, a Bácska és Baranya csatlakozását a Szerb Királysághoz, azaz a Zágráb versus Belgrád kérdésben a Szerb Királyság mellett döntött. További fontos fejlemény volt, hogy a Nagy Nemzetgyülés megválasztotta az 50 tagból álló Nagy Nemzeti Tanácsot, amely az operatív feladatok ellátására életre hívta a „Bánát, Bácska, Baranyai Nemzeti Igazgatóságot”, mely egy elnökből és 11 ,,miniszterből” állt. ${ }^{9}$

A Nagy Nemzetgyülés döntéseivel párhuzamosan a budapesti Károlyi-kormány és a megszállt Délvidék magyar hatóságai között a kapcsolat minimális szintre süllyedt, mivel a szerb hadsereg igyekezett hermetikusan lezárni a belgrádi konvencióban meghatározott demarkációs vonalat. ${ }^{10}$

\section{A legitimitás problémája}

A Nagy Nemzetgyülés döntéseivel, lépéseivel kapcsolatban azonban egy nagyon súlyos problémát kell rögzítenünk: a Nagy Nemzetgyülés küldötteinek etnikai összetétele az alábbi volt: a 757 küldöttböl 750 volt délszláv (578 szerb, 84 bunyevác, 62 szlovák, 21 ruszin 3 sokác, 2 horvát), a németeket 6 , míg a magyarokat 1 küldött képviselte. Érdemes összevetni a küldöttek etnikai összetételét és a Vajdaságban az 1921-es évben tartott népszámlálás eredményeit (1. táblázat).

\section{1. táblázat A Vajdaság etnikai viszonyai 1921-ben}

\begin{tabular}{|l|r|r|r|r|r|r|r|r|}
\hline Nemzetiség & \multicolumn{2}{|c|}{ Bácska } & \multicolumn{2}{c|}{ Bánát } & \multicolumn{2}{c|}{ Baranya } & \multicolumn{2}{c|}{ Vajdaság összesen } \\
\hline Magyar & 260998 & $35,5 \%$ & 984710 & $17,5 \%$ & 16638 & $33,8 \%$ & 376107 & $27,9 \%$ \\
\hline Német & 173796 & $23,6 \%$ & 126530 & $22,5 \%$ & 16253 & $32,9 \%$ & 316579 & $23,5 \%$ \\
\hline Szerb-horvát & 246598 & $33,5 \%$ & 240213 & $42,7 \%$ & 15604 & $31,6 \%$ & 502415 & $37,3 \%$ \\
\hline Román & 1182 & $0,1 \%$ & 67897 & $12,0 \%$ & 452 & $0,9 \%$ & 69530 & $5,2 \%$ \\
\hline Szlovák & 30993 & $4,2 \%$ & 17595 & $3,1 \%$ & 78 & $0,01 \%$ & 48666 & $3,6 \%$ \\
\hline Egyéb & 21551 & $3,1 \%$ & 12252 & $2,2 \%$ & 427 & $0,8 \%$ & 34230 & $2,5 \%$ \\
\hline Összesen & 735117 & $100,0 \%$ & 561958 & $100,0 \%$ & 49452 & $100,0 \%$ & 1346230 & $100,0 \%$ \\
\hline
\end{tabular}

Forrás: Gulyás László (2012): A Délvidék története. 2. kötet. A török kiüzésétől Trianonig 1683-

1920. Egyesület Közép-Európa Kutatására. Szeged. 89. old.

Látható, hogy a szerbek és a horvátok Vajdaság lakosságának mindössze 37,35\%-át adták, viszont ehhez képest az újvidéki népgyülésen elsöprő többségben képviseltették magukat. Azt gondoljuk, hogy ez mindenféleképpen a Wilson-féle önrendelkezés-elv megcsúfolása volt.

\footnotetext{
${ }^{8}$ A határozat teljes szövegét közli. Sajti Enikő (szerk.) 1988, 71-72.

${ }^{9}$ Gulyás László 2012/a, 94.

${ }^{10}$ Gulyás László 2016, 11-26.
} 
Az újvidéki Nagy Nemzetgyülést úgy értékelhetjük, hogy 1918 őszén, a Délvidéken minden szlávot (szerbek, bunyevácok, horvátok) megilletett az önrendelkezési jog, csak azt a két nemzetet - a magyarokat $(27,9 \%)$ és a németeket $(23,9 \%)$ - nem, pedig ők együtt a népesség több mint a felét alkották.

Kővágó László mutatott rá arra, hogy a versailles-i békekonferencián részt vevő jugoszláv küldöttség a Vajdaság etnikai viszonyaira való tekintettel tartózkodott attól, hogy a november 25-i határozatokra, mint a kérdéses terület államjogi helyzetét a népek önrendelkezési joga alapján meghatározó dokumentumra hivatkozzék. ${ }^{11}$ Ettől függetlenül a Vajdaság a jugoszláv állam keretei közé került, ahol mind a gazdasági, mind a politikai mezőben hátrányos megkülönböztetés határozta meg további sorsát. ${ }^{12}$

\section{Felhasznált irodalom}

Fogarassy László 1986, A magyar-délszláv kapcsolatok katonai története 1918-1921. Baranyai Helytörténetírás. Pécs.

Gulyás László 2005, Két régió - Felvidék és Vajdaság - sorsa az Osztrák-Magyar Monarchiától napjainkig. Budapest: Hazai Térségfejlesztő Rt.

Gulyás László 2012, A Délvidék története 2. A török kiüzésétöl Trianonig 1683-1920. Közép-Európai Monográfiák 6. Egyesület Közép-Európa Kutatására. Szeged.

Gulyás László 2013, A Délvidék története 3. Trianontól a királyi Jugoszlávia összeomlásáig. Közép-Európai Monográfiák. 8. Egyesület Közép-Európa Kutatására. Szeged.

Gulyás László 2016, A jugoszláv-magyar határ születése. in. Zombori István szerk. A szerbek Magyarországon 1918-1921. Budapest. Magyar Egyháztörténeti Enciklopédia Munkaközösség. 11-26. old.

Končar, Ranko 2008, Vasa Stajić és a Vajdaság Szerbiához történő csatlakozása. Létünk. 2008/3. szám 18-27.

Kővágó László 1964, A magyarországi délszlávok 1918-19-ben. Budapest: Akadémiai Kiadó.

Mészáros Sándor 1998, A Világháború befejezése. A Vajdaság részvétele a magyarországi polgári demokratikus forradalomban. In. Csorba Béla-Nagy Tibor szerk. (1998): Árnyéka eltünő nevemnek... Források a Délvidék történetéhez. Hatodik Síp Alapítvány. Budapest. 260-265. old.

Sajti Enikő (szerk.) 1988, Jugoszlávia 1918-1941. Dokumentumok. Társadalomtudományi Kör. Szeged.

Sokcsevits Dénes 2011, Horvátország. A 7. századtól napjainkig. Budapest: Mundus Novus.

A müre a Creative Commons 4.0 standard licenc alábbi típusa vonatkozik: CC-BY-NC-ND-4.0.

\section{$(c))$ BY-NC-NO}

\footnotetext{
${ }^{11}$ Kővágó 1964, 98.

${ }^{12}$ Bővebben lásd Gulyás László 2005, 89-93.; Gulyás László 2013.
} 